\title{
Active learning in online classes
}

\author{
Samaneh Niktinat \\ Private institution, Iran-Mashhad
}

\begin{abstract}
Education is an area that has recently seen considerable changes as a result of the global spread of coronavirus (COVID-19). Instead of traditional classes with students seated in neat rows, faces turned to the teacher, a current online class is a screen with tiny boxes showing faces, pictures, or letters that represent students. Having several advantages such as being accessible, easy to use, and affordable, this new form of education brings about some challenges including a high level of distraction and lower student engagement (Friedman, 2020). Therefore, applying techniques to actively engage students and keep them engaged during an online session is important. Studies have shown active learning methods enhance student's engagement, performance, and attitude in the traditional format. Considering the benefit of active learning and the rise in the use of online classes during the covid pandemic, this paper aimed to examine the effectiveness of implementing some active learning methods in the online setting. To reach this aim, two active learning strategies including flip learning and group work were applied in five online classes of high school students. The data was gathered from both students' reflections on their learning and teacher interviews to assess how much active learning was successful in providing an effective and inclusive virtual environment and improving student's engagement and learning achievements. Overall, the result depicted that despite some limitations, similarly to traditional classes, applying active learning methods are helpful in online classes which increases students' engagement, performance and achievement to a great extent.
\end{abstract}

Keywords: traditional classes, online classes, active learning, student engagement

\section{Literature review}

Teaching is not pouring knowledge into students' heads, it is providing an opportunity for them to make sense, experience, explore and construct their learning. In such an environment, teachers are not transmitters of knowledge, but they play a role of a mediator, facilitator, organizer, and consultant. This sort of learning process demands a high level of engagement from the students' side. "To teach is to engage students in learning." (Christensen et al., 1991, p. foreword, xiii). A variety of learning methods, such as collaborative learning, cooperative learning, and problem-based learning can be employed to promote student engagement and provide such an efficient learning environment (Prince, 2004; Prince and Felder, 2007). All these methods fit into a category of pedagogy called "active learning." 
Dublin, Ireland

Active learning has gained growing interest recently. While it is a wide concept that has a variety of definitions. Bonwell and Eison defined strategies that promote active learning as "instructional activities involving students in doing things and thinking about what they are doing" (Bonwell and Eison, 1991). Felder and Brent (2009) define active learning as "anything course-related that all students in a class session are called upon to do other than simply watching, listening and taking notes". Active learning is not a theory but a teaching method that supports learning. It uses techniques such as writing reflections, discussion and problem-solving activities that promote analysis, synthesis, and evaluation and guides students towards achieving higher thinking levels (Morrison, 2015). Approaches that promote active learning focus more on developing students' skills than on transmitting the information. Moreover, active learning methods also tend to emphasis on students' explorations of their attitudes and values.

Conceptually, active learning and its theoretical roots are in constructivist learning theories. Constructivism views learning as a construction process and emphasizes that individuals learn through building their knowledge, connecting new ideas and experiences to existing knowledge and experiences to form new or enhanced understanding (Bransford et al., 1999). It highlights understanding instead of memorizing and aims to enhance deep understanding in students. Nevertheless, it is not easy to define aspects of an effective constructivist teaching because it is a theory of learning and not a theory of teaching (Richardson, 2003). For example, active learning as an instructional approach aims to enable constructivist learning by emphasizing on students' self-construction of knowledge, and students' responsibility for their learning. However, instruction that aims to be constructivist often fails to elicit prior knowledge and apply them, connect the prior and the new knowledge, and evoke reflection on learning. Therefore, active learning is not just something that students do on their own but should be organized and monitored by a teacher to reach the proposed aims and increase student engagement.

Active learning approaches often embrace the use of cooperative learning groups. Moreover, a constructivist-based practice places particular emphasis on the contribution of social interaction. Lev Vygotsky's work elucidated the relationship between cognitive processes and social activities and resulted in the sociocultural theory of development, which suggests that learning takes place when students solve problems beyond their current developmental level with the support of their teachers or their peers (Vygotsky, 1978). Thus, active learning activities that rely on group work and rest on this sociocultural branch of constructivist learning theory, escalate peerpeer interaction and promote students' achievement from their learning process.

While providing an environment for students to actively learn, think and reflect on their learning is not easy in the traditional learning environment, an online setting makes it more challenging. For many students, one of the biggest challenges of online learning is the struggle with focusing on the screen for long periods. With online learning, there is also a greater chance for students to be easily distracted by social media or other sites (Schmidt, 2021). The other challenge is that there is a low level of interaction in online 
classes, but many active learning techniques are designed for traditional classes and are heavily dependent upon face-to-face interaction (e.g., discussion, group work, roleplay). Moreover, online learning requires teachers to have a basic understanding of using digital forms of learning. However, this is not the case always. teachers often have a very basic understanding of technology. Therefore, having attractive, engaging, and interactive online active classes addressing these challenges seems necessary.

Teachers as instructors can play an important role in addressing challenges and facilitating a sound active online class. To do this, teachers should implement active learning pedagogies that support learning objectives, but structure them to work online, outside of the traditional classroom environment. Moreover, they should keep in mind the students' high level of distraction in online classes and help them to stay focused while working in the class. To facilitate a good online class, teachers are better to consider several factors including providing an inclusive environment for the learners to feel connected, implementing a variety of appropriate instructional tools and techniques for delivery, developing supporting strategies in the form of directions and resources, incorporating assessment of learning outcomes, and designing activities with active engagement and online condition in mind (Mantyla, 1999). Starting from a basic instructional design model and continuing good teaching practices are important because according to Moore and Kearsley (1996), "active learning is probably not going to happen in an online environment unless the interaction is deliberately planned, and the instructor encourages it".

While the term active learning encompasses a broad array of practices, collaborative learning, or small group work, appears to be an important element of active learning theory and practice. Collaborative learning or group work is an instructional approach in which students work together in small or large groups to accomplish a common learning goal or a well-defined learning task (Rezaei, 2015). There are various reasons why educators employ group activities in the teaching and learning process. Group work is effective in motivating students, encouraging active learning, and developing key critical thinking, communication, and decision-making skills. Many research studies supporting the idea that collaborative methods have a positive effect on student achievement in almost any discipline (Bennett, 2015; Katz and Rezaei, 1999 and Rezaei, 2015). According to McConnell:

"These types of virtual communities provide participants with the opportunity to take ownership over the content and direction of their learning; be responsible for managing their learning and cooperate; and to focus on their own learning and development from a critical, reflective perspective, combined with an understanding of relevant academic ideas and concepts" (2006, p.31).

Collaborative learning is a key teaching strategy to use to reinforce skills such as students' communicative abilities and critical thinking. Groupwork can provide an environment of learning that students learn from each other and support their learning. 
Therefore, it is an ideal environment for transforming students from passive recipients of information to active participants in the learning process.

Besides the advantages mentioned above, group work can be beneficial in online classes in multiple ways. Conrad and Donaldson (2004) argue that group work in online learning environments involves students in interaction and sharing ideas which trigger deeper processing of content. Moreover, virtual group work promotes higher-order thinking, critical thinking. Another major benefit is in increasing students' interpersonal communication skills. Scholars have stressed that group interaction in online learning environments promotes effective interaction (Driver, 2002). Whereas online learning causes social isolation. To elaborate on, in the online setting, there is no time before or after school and no traditional breaks for students to communicate and talk to each other down the hall or in the schoolyard. By providing an opportunity for students to interact, group work can be effective in increasing students' communication. Moreover, lack of time is always a problem in online classes. The fact that through group work, students operate within set time parameters helps in the development of good time management.

Despite the advantages mentioned above, group work is perceived to be more challenging in online classes than face-to-face ones. Setting groups, breaking ices between group members who are not very familiar with each other, communication deficiencies, lack of a sense of community and being more time-consuming are some issues that need to be considered when applying online collaborative activity. For example, online group work among distance learners lacks some of the social interaction that occurs in face-to-face settings (Krejins and Kirschner, 2004). This may result in unfamiliarity among group members, which can lead to deficient group dynamics (Fung, 2004). Online collaborative groups may also go through delayed group developmental stages, taking longer to develop social relationships (Fung, 2004). Considering drawbacks mentioned above, it is upon the instructor to apply strategies for addressing problems and facilitating a fruitful group learning method using icebreaking activities, giving groups more time to develop a relationship, dividing responsibilities among them and observe group works, give them feedback and intervein whenever necessary.

The flipping learning is another active learning method that has been studied in this survey. While many teachers and educators are looking for active and creative methods to increase students' engagement in classes, "flipped learning" as an innovative active learning method has attracted much attention (Chung et al., 2019). The concept is defined as a

"Pedagogical approach in which direct instruction moves from the group learning space to the individual learning space, and the resulting group space is transformed into a dynamic, interactive learning environment where the educator guides students as they apply concepts and engage creatively in the subject matter" (Flipped Learning Network, 2014, para. 4). 


\section{3rd International Conference on Modern Research in EDUCATION, TEACHING AND LEARNING}

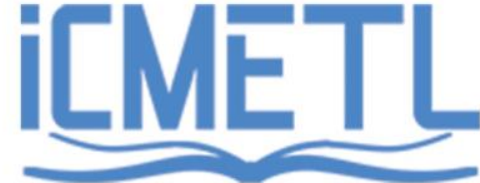

20 - 22 August 2021

Dublin, Ireland

In this approach, the classroom instruction and homework activities are flipped allowing the instructor greater use of class time to get into the topic at a much deeper level involving higher-order thinking skills and real-world applications. Flipped learning is seen as a blended learning model where part of the instruction is conducted via technology and part of the education takes place in-person and is generally found to be more effective than fully face-to-face classrooms (Fazal and Bryant, 2019).

One of the advantages of flipped classes is in allowing students to complete learning covered in the classroom at their own pace and time (by watching videos, accessing resources, completing formative assessments), dedicating classroom time to experiential activities and interactive, personalized learning. When using video, for example, students can pause, rewind, and review the lesson at any time. In class, the teacher and students can then focus on the upper levels of the taxonomy (applying, analyzing, and creating). Furthermore, this approach is posited to improve student engagement in learning and in motivation to learn (Akcayir and Akcayir, 2018; Perez et al., 2019). It provides a bridge to a learner-centered classroom environment, thereby enabling deeper learning (Bergmann and Sams, 2012). Additionally, using this method, students can take ownership of their learning, as well as receive immediate support and guidance in class (Anderman et al., 2011).

Flipped learning seems to be an appropriate method to increase students' engagement in online classes. While lack of interaction between teacher and students is a challenge of online classes, flipped learning allows for multi-modal interactions that can be used more extensively and effectively. Moreover, flipped learning enhances meaningful input and interaction (Gillies, 2006 and Krashen, 2014) by ensuring that students control the out-of-class content individually and apply this new content in communicative activities during class (Brinks-Lockwood, 2014). In addition, while in online classes, lack of a schedule, too many distractions and multitasking can lead to poor time management, flip learning can help to better use the class time and increase student engagement outside the classroom by moving delivery of content to the out-ofclass portion of the course. A major benefit for teachers is that flipped learning frees up time and uses their energy to observe, feedback, and assessment (Marshall and DeCapua, 2013). It can also be a viable mean to address the educational challenges. For example, there are numerous reasons for students' low attendance in their online classes including not having access to electronic devices and an internet connection, poverty, family responsibilities and student laziness. Through flipped learning, teachers can be ensured that those students who were missing class because of technological issues and other obstacles could still access the content.

\section{Methodology}

As aforementioned, this research studied the effect of two active learning pedagogies, group work and flipped learning, on students' learning and engagement in online classes. To meet this aim, we surveyed students of five online classes in a private institution taught by five different faculties. The size of surveyed classes was between 


\section{3rd International Conference on Modern Research in EDUCATION, TEACHING AND LEARNING}

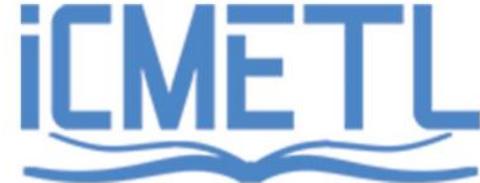

20 - 22 August 2021

Dublin, Ireland

10 to 15 and history was taught to students using different active learning methods. Table 1 provides a summary of students who were in this study.

\begin{tabular}{|l|l|l|l|}
\hline Information & Level & Number of students & Percentages (\%) \\
\hline \multirow{4}{*}{ age } & $12-14$ & 26 & 38 \\
\cline { 2 - 4 } & $14-16$ & 23 & 34 \\
\cline { 2 - 4 } & $16-18$ & 19 & 28 \\
\cline { 2 - 4 } & other & 0 & 0 \\
\hline \multirow{5}{*}{ gender } & male & 37 & 54 \\
\cline { 2 - 4 } & female & 31 & 46 \\
\hline Subject of study & history & 68 & 100 \\
\hline \multirow{5}{*}{ class } & Class A & 12 & 18 \\
\cline { 2 - 4 } & Class B & 14 & 20.5 \\
\cline { 2 - 4 } & Class C & 15 & 22 \\
\cline { 2 - 4 } & Class D & 14 & 20.5 \\
\cline { 2 - 4 } & Class E & 13 & 19 \\
\hline
\end{tabular}

Table 1: summary about students in this study

Two active learning methods including group work and fillip learning were implemented in different sessions of classes A to E. A mixed-methods design was used for this research. Creswell (1999) indicated that a mixed-methods approach, using both quantitative (predominately closed-ended response survey) and qualitative methods (interview and open-ended questions), is a valuable strategy when studying complex environments. According to Bonwell and Eison 1991, active learning is involving students in doing things and thinking about what they are doing. Moreover, in an active learning process, students become responsible for their learning and can better help in evaluating the effectiveness of outcomes, pedagogies and their learning process as a whole. Therefore, this study collected data from both students and their teachers.

To have teachers' views and feedback on applying active learning methods, teachers were interviewed after each class. The interview is one of the most popular methods in qualitative research and provides "in-depth information about participants' experiences and viewpoints of a particular topic" (Turner, 2010, p.775). at the end of each session, teacher had time to state any feedback or comment they have on the whole lesson and specifically about the method they have implemented. During interviews, teachers were asked to share their general feedback on the lesson and how do they think it was. They were also requested to express the highs and lows about the learning method they applied by answering the following questions: 'what was the best part of the lesson for you?" and 'what was the worst part of it?'. Having teachers' consent, all interviews were being recorded to be analysed after. Moreover, all data and information from both teachers and students were kept anonymously and safely in strict confidentiality using methods such as pseudonyms and coding. 
For gathering data from students, this study made use of a questionnaire. The questionnaire is one of the most popular and well-established tools for acquiring quick and intended data in the social sciences and educational research (Bulmer, 2004). The questionnaire in this survey contained some factual, some rating scale and open-ended questions. Factual questions helped to provide general information about students such as their age, sex and class. Rating scales questions were used to represent respondent feedback in a comparative form for particular features of learning methods. Finally, open-ended questions were applied to allow participants to freely state their thoughts, understandings and opinions about the topic. At the end of each session, questionnaires were given to students to guide their reflection and help them in evaluating the applied learning method and share their viewpoints on it (appendices A). To better gather data from all students about each class, it was decided to give students some time at the end of each lesson and ask them to fill the questionnaire while they were still in the class. The result provided here is from teachers' interviews and student's answers to the questionnaire.

To implement the online group work method, students of five classes were being divided into groups of 4-5. There was one zoom breakout room for each group. Groups were asked to go to their breakout rooms for talking, sharing ideas, discussing and working together. They had to collaboratively make a storyboard for a period of history using information from the textbook. Each group had a Canva (an online graphic design platform) link to make their storyboard on it and they were familiar with the website and used it before. After finishing their works, groups were also supposed to present their works to the whole class. In order to better manage the class time, groups knew the timing in advance and got a notification about it every five minutes. For addressing the challenge of less sense of community and breaking ice, groups were asked to play two truth and a lie game at the beginning of their classes.

For implementing flipped learning in this survey, students of five history classes were instructed to go through a package of content that was given to them before the class containing some short videos, and few pages from the textbook at home. By doing so, class time could be freed up to be spent on more interactive learning methods. As it was predicted, not all students reviewed the package before the class. Some of them have read the texts and many of them watched the video which illustrates that video is more attractive for students of this age group. At the beginning of each class, few students were asked to provide a summary of what they have learned to their peers to review the content. During class time, students were asked to use what they have learned from the package to have a silent debate on a historical event. They had to write their viewpoint on the cause, importance and result of that event on a padlet (real-time collaborative web platform) and react, comment on each other viewpoints and answer comments. 
Dublin, Ireland

\section{Results}

From 68 students who were the target sample of this survey, four were absent and not answered to the questionnaire for group work sessions and two were absent for flipped learning classes. Students' answers to close-ended questions (question number one to number four of the questionnaire) for group work activity are summarised below:

\begin{tabular}{|c|c|c|c|c|c|c|c|}
\hline Question rate & $\begin{array}{l}1 \\
\text { poor }\end{array}$ & $\begin{array}{l}2 \\
\text { fair }\end{array}$ & $\begin{array}{l}3 \\
\text { good }\end{array}$ & $\begin{array}{l}4 \\
\text { Very } \\
\text { good }\end{array}$ & $\begin{array}{l}5 \\
\text { excelle } \\
\text { nt }\end{array}$ & $\begin{array}{l}\text { Not } \\
\text { answere } \\
\text { d }\end{array}$ & total \\
\hline \multirow{2}{*}{$\begin{array}{l}\text { 1. How much do } \\
\text { you think you } \\
\text { were engaged in } \\
\text { the lesson } \\
\text { throughout the } \\
\text { session? (from } 1 \\
\text { to 5) }\end{array}$} & 1 & 3 & 15 & 22 & 23 & 4 & 68 \\
\hline & $1.47 \%$ & $4.41 \%$ & $22.06 \%$ & $32.35 \%$ & $33.82 \%$ & $5.88 \%$ & $100 \%$ \\
\hline \multirow{2}{*}{$\begin{array}{l}\text { 2. How would you } \\
\text { grade your effort } \\
\text { and attention } \\
\text { level when } \\
\text { learning/ trying } \\
\text { to learn this } \\
\text { topic? (from } 1 \text { to } \\
\text { 5) }\end{array}$} & 0 & 0 & 3 & 17 & 44 & 4 & 68 \\
\hline & $0.00 \%$ & $0.00 \%$ & $4.41 \%$ & $25.00 \%$ & $64.71 \%$ & $5.88 \%$ & $100 \%$ \\
\hline \multirow{2}{*}{$\begin{array}{l}\text { 3. How much you } \\
\text { were aware of } \\
\text { the learning } \\
\text { objectives and } \\
\text { process through } \\
\text { the session? } \\
\text { (from } 1 \text { to 5) }\end{array}$} & 0 & 0 & 0 & 33 & 31 & 4 & 68 \\
\hline & $0.00 \%$ & $0.00 \%$ & $0.00 \%$ & $48.53 \%$ & $45.59 \%$ & $5.88 \%$ & $100 \%$ \\
\hline \multirow{2}{*}{$\begin{array}{l}\text { 4. How would you } \\
\text { grade your } \\
\text { current } \\
\text { understanding or } \\
\text { mastery of this }\end{array}$} & 1 & 1 & 12 & 15 & 35 & 4 & 68 \\
\hline & $1.47 \%$ & $1.47 \%$ & $17.65 \%$ & $22.06 \%$ & $51.47 \%$ & $5.88 \%$ & $100 \%$ \\
\hline
\end{tabular}




\section{3rd International Conference on Modern Research in EDUCATION, TEACHING AND LEARNING}

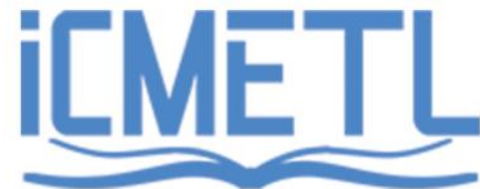

20 - 22 August 2021

Dublin, Ireland

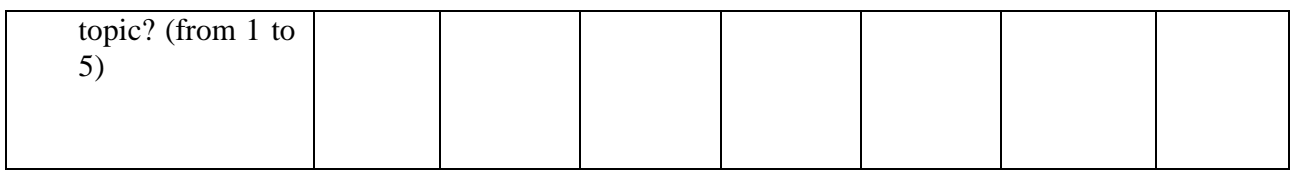

Table 2: summary of students' answers about group work

The above table illustrates $88 \%$ of participants believed they were highly engaged during group work. There was a student who rated this item poor and explained in her questionnaire that she was disconnected most of the class time because of technological issues. While distraction is a major challenge of online classes, the results indicate using group work $64 \%$ of students think their attention level was excellent. The findings depict that no students think their awareness of objective and process was poor, fair or even good and all of them were very satisfied with group work. While most students (nearly 73\%) grade their understanding of the topic high, two students asserted it was poor and fair. One of these students is the one who had a connection problem.

For question number 5 which was 'who do you think had the main responsibility during the lesson? Teacher or students? Almost all of the students asserted that they were more responsible in their lesson than their teacher. Overall, participants expressed that they valued the group work pedagogy because it provided an opportunity for them to interact with their peers, share their learning and support each other. A student explained that "I learn much more by working in groups than working individually. I obtain more through interaction with the other group members, and I am happy we had group work in our online class." Another student stated "I feel more motivated when I work with a group. I enjoyed having other people around. I think that everyone had something different to contribute to an effort and this helped in fulfilling the task better". Several students expressed they had fun in their groups enjoyed working with their peers. Most of them said group work was the best part of the lesson for them.

At the same time, there were difficulties in successfully applying for the group work in a fully online class. The main challenge identified was the lack of time. According to a student, "The workload was overwhelming. Umm, I think we all felt very stressed out during that class because we had so much to accomplish in such a short period of time". Results also showed several groups did not finish their tasks on the given time and some students stated this as the worst part of the lesson. Therefore, while doing group work, time needs to be carefully allocated considering factors such as delay in connection, internet problems and limitations. The limitation of being unfamiliar with each other and lack of communication was also identified in students' answers. A student expressed: "Without being able to fully see each other's faces, it's hard to understand others, their reactions and what they really mean".

Teachers' feedback on implementing group work was mainly positive and there were very few problems they stressed in their answers. One of them said that "using group work as a pedagogy in an online setting was an invaluable experience. I always worry 
Dublin, Ireland

about lack of communication in virtual classes. The problem that group work addressed in the best way". Another teacher explained the problem of having one way and very teacher-centred classes were solved using this method. Talking about the class environment when using group work a teacher expressed "working in groups helps students to learn in a more convenient and comfortable environment which is motivating and enhance their engagement enormously". On the other hand, "lack of the sense of communication", "unequal participation", "being easy to avoid work" and "the issue of time" are some drawbacks that teachers expressed in their answers and need to be considered while applying this method.

Students answers to the first four questions after implementing flipped learning are as following:

\begin{tabular}{|c|c|c|c|c|c|c|c|}
\hline Questions & $\begin{array}{l}1 \\
\text { poor }\end{array}$ & fair & $\begin{array}{l}3 \\
\text { good }\end{array}$ & $\begin{array}{l}4 \\
\text { Very } \\
\text { good }\end{array}$ & $\begin{array}{l}5 \\
\text { excellen } \\
t\end{array}$ & $\begin{array}{l}\text { Not } \\
\text { answered }\end{array}$ & total \\
\hline \multirow{2}{*}{$\begin{array}{l}\text { 5. How much do you } \\
\text { think you were } \\
\text { engaged in the } \\
\text { lesson throughout } \\
\text { the session? (from } 1 \\
\text { to 5) }\end{array}$} & 0 & 5 & 13 & 20 & 28 & 2 & 68 \\
\hline & $0.00 \%$ & $7.35 \%$ & $19.12 \%$ & $29.41 \%$ & $41.18 \%$ & $2.94 \%$ & $100 \%$ \\
\hline \multirow{2}{*}{$\begin{array}{l}\text { 6. How would you } \\
\text { grade your effort } \\
\text { and attention level } \\
\text { when learning/ } \\
\text { trying to learn this } \\
\text { topic? (from } 1 \text { to 5) }\end{array}$} & 0 & 4 & 9 & 17 & 37 & 2 & 68 \\
\hline & $0.00 \%$ & $5.88 \%$ & $13.24 \%$ & $25.00 \%$ & $54.41 \%$ & $2.94 \%$ & $100 \%$ \\
\hline \multirow{2}{*}{$\begin{array}{l}\text { 7. How much you } \\
\text { were aware of the } \\
\text { learning objectives } \\
\text { and process } \\
\text { through the } \\
\text { session? (from } 1 \text { to } \\
\text { 5) }\end{array}$} & 3 & 12 & 8 & 26 & 17 & 2 & 68 \\
\hline & $4.42 \%$ & $17.65 \%$ & $11.76 \%$ & $38.24 \%$ & $25.00 \%$ & $2.94 \%$ & $100 \%$ \\
\hline $\begin{array}{l}\text { 8. How would you } \\
\text { grade your current } \\
\text { understanding or }\end{array}$ & 0 & 0 & 18 & 18 & 30 & 2 & 68 \\
\hline
\end{tabular}




\section{3rd International Conference on Modern Research in EDUCATION, TEACHING AND LEARNING}

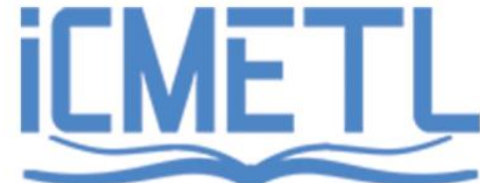

20 - 22 August 2021

Dublin, Ireland

\begin{tabular}{|l|l|l|l|l|l|l|l|}
\hline $\begin{array}{l}\text { mastery of this } \\
\text { topic? (from 1 to 5) }\end{array}$ & $0.00 \%$ & $0.00 \%$ & $26.47 \%$ & $26.47 \%$ & $44.12 \%$ & $2.94 \%$ & $100 \%$ \\
\hline
\end{tabular}

Table 3: summary of students' answers about flipped learning

The result shows nearly $70 \%$ of students level their engagement very good and excellent through flipped learning method. While only one student said his attention was poor during the session, about $92 \%$ of students rank their attention good, very good and excellent. About being aware of the objective and process, the result illustrates students were less happy with and 12 of them said it was fair while only 17 of them stated it was excellent. This was not very much about flipped learning and besides applying this method, teachers were expected to clarify the learning process and objective which is a must for all teachers in every class. The result showed that probably some teachers have forgotten about it. while no student grade his/her understanding of the topic poor, near $97 \%$ of students level it high and upper.

Similar to the group work activity, for question number 5 most students (about 87\%) stressed they think they were more responsible in the learning process. This depicts that flipped learning was successful as an active learning method to give students main responsibility. Of the students surveyed, many of them agreed that by flipping their classrooms, learning became more interactive and active, and this was their high point of the lesson. Some of them highlighted that they usually became distracted and lose some part of the lesson and that was very annoying for them and resulted in their poor participation in the class. However, by flipped learning, they have greater opportunities to work at their own pace and time to better master the lesson. A student expressed "being active on an online board at the same time and watching each other writing was interesting and inspired me to take part". A student described the lesson as an opportunity for her to express her ideas, while she is shy and does not very expressive during classes. Another student said that "accessing a rich and appropriate content helped me to be more confident about myself while working in the class".

Of the educators surveyed, all of them were agreed that students became more active and engaged during the flipped lesson. A teacher explained learning at their own pace and time enables students to come to class better prepared and this impact their level of engagement enormously. Teachers were all also pleased that using this method enabled them to move from low-level activities such as memorizing and understanding and focus on higher levels of thinking including applying, analysing, and creating. One of them said that "this was always my major concern to find ways to increase student's level of thinking, which is a big challenge especially in online classes, I am very happy that flipping learning helped me in this regard". Another teacher explained that "I like this flip learning because by eliminating lecture and other means of instruction, I have more time to spend with each student individually, observe them while working, help them if required, provide them with feedback relevant in the moment, and continuously 


\section{3rd International Conference on Modern Research in EDUCATION, TEACHING AND LEARNING}

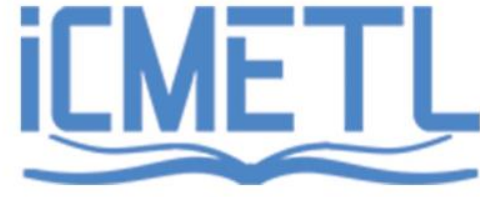

20 - 22 August 2021

Dublin, Ireland

assess their works". In terms of increasing students' interaction with each other and with the teacher, four out of five studied teachers mentioned it as their high point of the lesson.

Although a majority of teachers' feedback on flipped classes was positive, there were some drawbacks and issues they pointed during their interviews. The main challenge that some of them notify was about time. One of them said that "while it is called student-centered learning approach, it required more time from teachers to plan the lesson, prepare resources and content, set up the tools and equipment for technology support and develop appropriate activities". Similarly, another teacher explained that "I think time is the main issue of online flipped classes. In one hand, it is demanded from teachers to devote more time and effort to plan and implement flipped lessons, and on the other hand, time management is a difficult task for learners, as online courses require a lot of time and intensive work". Given this requirement, two interviewed teachers pointed that working as a team while planning for flipped class and share resources similarly with other teachers could help when applying this method.

\section{Conclusion}

From this study, we can ascertain that similarly to face to face classes active learning methods could be prosperous in an online setting in improving student engagement, interactions and learning. Moreover, applying these methods provides support for students' higher order thinking and deepens their learning which is a generally accepted aim of many educational systems. In addition, implementing active learning pedagogies is specifically important for online classes to overcome challenges in time management, higher level of student distractions, limitations in technology, difficulty in communication and lower student engagement. However, more qualitative and quantitative research needs to be done to address challenges and identify the best ways to maximize the effectiveness of active learning methods in online learning.

\section{References}

Akcayir, G., and Akcayir, M. (2018). The flipped classroom: A review of its advantages and challenges. Computers and Education, 126, 334-345.

Anderman, L. H., Andrzejewski, C. E., and Allen, J. (2011). How do teachers support students' motivation and learning in their classrooms? Teachers College Record,113, 969-1003.

Bennett, T. (2015). Group Work for the Good; Unpacking the Research behind One Popular Classroom Strategy. American Educator, 1, 32-43

Bergmann, J., and Sams, A. (2012). Flip your classroom: Reach every student in every class every day. Alexandria, VA: Association for Supervision and Curriculum Development. 
Bonwell, C. C., and Eison, J.A. (1991). Active learning: creating excitement in the classroom. ASH\#-ERIC Higher Education Report No. 1, Washington, D.C.: The George Washington University, School of Education and Human Development.

Bransford, J.D., Brown, A.L., and Cocking, R.R. (Eds.) (1999). How people learn: Brain, mind, experience, and school. Washington, D.C.: National Academy Press.

Brinks-Lockwood, R. (2014). Flip it! Strategies for the ESL classroom. Ann Arbor, MI: University of Michigan Press.

Bulmer, M. (2004). Questionnaires (1st ed.), London, SAGE publications.

Creswell, J. W. (1999). Mixed-method research: Introduction and application. In G. J.Christensen, C. R., Garvin, D. A., \& Sweet, A. (1991). Education for judgment: The artistry of discussion leadership. Cambridge, MA: Harvard Business School.

Chung, C. J., Lai, C. L., and Hwang, G. J. (2019). Roles and research trends of flipped classrooms in nursing education: A review of academic publications from 2010 to 2017. Interactive Learning Environments, 1-22.

Conrad, R.-M., and Donaldson, J. A. (2004). Engaging the online learner: Activities and resources for creative instruction. San Francisco: Jossey-Bass Inc.

Driver, M. (2002). Exploring student perceptions of group interaction and class satisfaction in the web-enhanced classroom. The Internet and Higher Education, 5(1), $35-45$

Fazal, M. and Bryant, M. (2019). Blended learning in middle school math: The question of effectiveness. Journal of Online Learning Research, 5(1), 49-64.

Felder, R.M.; Brent, R. Active learning: An introduction. ASQ High. Educ. Brief 2009, 2, 4-9.

Flipped Learning Network (FLN). (2014). What is flipped learning? Retrieved from http://fln.schoolwires.net/cms/lib07/VA01923112/Centricity/Domain/46/FLIP_hando utFLN_Web.pdf.

Friedman, J. (2020). The challenges of pivoting to online classes and how to tackle them. https://www.usnews.com/education/best-colleges/articles/how-toovercomechallenges-of-online-classes-due-to-coronavirus

Fung, Y. H. (2004). Collaborative online learning: Interaction patterns and limiting factors. Open Learning, 19(2), 135-149.

Gillies, R. (2006). Teachers' and students' verbal behaviours during cooperative and small-group learning. British Journal of Educational Psychology,76, 271-287.

Katz, L., and Rezaei, A. (1999). The potentials of modern Tele-learning tools for collaborative learning. Canadian Journal of Communication, 24(3), 427-448.

Krashen, S. (2014). Case histories and the comprehension hypothesis. TESOL Journal, 9. Retrieved from http://www.sdkrashen.com/content/articles/ skrashen_case_histories.pdf.

Krejins, K., and Kirschner, P. (2004). Designing social CSCL environments: Applying interaction design principles. In J.-W. Strijbos, P. A. Kirschner \& R. L. Martens (Eds.), What we know about CSCL and implementing it in higher education, 221-243. Mantyla, K. (1999). Interactive distance learning exercises the really work! Alexandria, VA: American Socity for Training and Development. 
Marshall, H. W., and DeCapua, A. (2013). Making the transition to classroom success: Culturally responsive teaching for struggling language learners. Ann Arbor, MI: University of Michigan Press.

Moore, M. G. \& Kearsley, G. (1996). Distance education: A systems view. Belmont, CA: Wadsworth Publishing Company.

Morrison, D. (2015) Four-Step Strategy to Create Active Learning in Any Learning Space - Online, F2F or Blended, Online Learning Insights. Available at: https://onlinelearninginsights.wordpress.com/2015/09/02/four-step-strategy-tocreate-active-learning-in-any-learning-space-online-f2f-or-blended/

Perez, A., Collado, J., Garcia de los Salmones, M. del M., Herrero, A., and Martin, H. S. (2019). An empirical exploration of the perceived effectiveness of a "flipped classroom" in a business communication course. Journal of the Scholarship of Teaching and Learning, 19(2), 47-65.

Prince, M. (2004). Does active learning work? A review of the research. Journal of Engineering Education, 93(3), 223-231.

Prince, M., and Felder, R. (2007). Too many faces of inductive teaching and learning. Journal of College Science Teaching, 36(5), 14-20.

Rezaei, A. R. (2015). Frequent collaborative quiz taking and conceptual learning. Active Learning in Higher Education, 16(3), 187-196.

Richardson, V. (2003) Constructivist pedagogy. Teach. Coll. Rec., 105, 1623-1640

Flipped Learning Network (FLN). (2014). What is flipped learning? Retrieved from http://fln.schoolwires.net/cms/lib07/VA01923112/Centricity/Domain/46/FLIP_hando utFLN_Web.pdf

Schmidt, S. J., (2021) The Academic Safety Net: Empowering and Motivating Our Students to Do Their Best Work, Journal of Food Science Education, 10.1111/15414329.12218, 20, 1, (2-7).

Turner, D. W. (2010). Qualitative Interview Design: A Practical Guide for Novice Investigators. The Qualitative Report, 15(3), pp.754-760.

McConnell, D. (2006). E-learning groups and communities. Berkshire: Open University Press

Vygotsky, L. S. (1978). Mind in society. Cambridge, MA: Harvard University Press.

\section{Appendix A (Questionnaire from students):}

- How much do you think you were engaged in the lesson throughout the session?

- How would you grade your effort and attention level when learning/ trying to learn this topic?

- How much you were aware of the learning objectives and process through the session?

- How would you grade your current understanding or mastery of this topic? (from 1 to 5)

- Who do you think had the main responsibility during the lesson? Teacher or students

- What did you like the most from today's lesson? 
Dublin, Ireland

- What did you like the least from today's lesson?

- Did the lesson meet your anticipation and understanding of an ideal class, why?

- What method, tools would you use to teach this topic to a friend? 